MedieKultur | Journal of media and communication research | ISSN 1901-9726

Book Review

Stine Liv Johansen

\title{
Chris Davies, John Coleman and Sonia Livingstone: Digital Technologies in the Lives of Young People. London: Routledge. 2014
}

\author{
Sonia Livingstone and Julian Sefton-Green: \\ The Class. Living and Learning in the Digital Age. \\ New York University Press. 2016
}

MedieKultur 2016, 61, 178-181

Published by SMID | Society of Media researchers In Denmark | www.smid.dk The online version of this text can be found open access at www.mediekultur.dk

Children's and young people's lives in general and their media usage in particular are surrounded by much concern and debate. This debate tends to highlight negative concerns rather than positive aspects, as well as adults' concerns rather than children's and adolescents' own voices. Fortunately, quite a few scholars have taken up the task of trying to nuance these black and white, cause and effect studies. Digital Technologies in the Lives of Young People (2014) presents seven articles based on theoretical discussions and empirical inquiries that mostly focus on the uses and conceptualizations of digital technologies by teenagers in their everyday life. In his introduction, John Coleman outlines some of the common themes touched upon by all of the book's contributors, focusing on three aspects which form part of the foundation of our understandings of the topic.

First, age is important. Children and young people are always seen in terms of their age, and the contributions in this volume set out to apply a fruitful notion of the specificities related to young people's needs and interests. Second, discussions of (young) people's uses of technologies need a proper definition or discussion of what 'the technological' implies. Scholars often adopt a soft deterministic or constructivist view of technologies and the role they play in people's lives, while public debates tend to be founded on a discourse of technological determinism. Third, the notion of learning in both formal and informal settings is part of the broader picture that the contributors to this book are trying to paint. 
In her chapter, Sonia Livingstone raises a fundamental critique of the ways in which digital technologies are used and framed within the (British) school system. She questions the common belief that ICT hardware and software have a particularly positive impact on standardized test results and on students' academic achievements across subjects. Evaluations and studies have proved unable to come up with significant conclusions on these issues, while governments all over the Western world continue to make massive investments in ICT in schools. Things are beginning to change though, and different ways of thinking about participatory culture (as inspired by Jenkins and others) seem to add new ways of discussing and understanding what ICT in school could and should mean. These discussions have developed in the last couple of years, and in Denmark, for instance, Tække and Paulsen's (2016a, 2016b) action research-based approaches have challenged extant understandings of digital media in the classroom.

Ola Erstad presents a cross-cutting understanding of young people's learning trajectories, introducing the notion of a 'learning lives approach'. Theoretical and methodological approaches should be able to grasp that young people move between formal and informal learning contexts, online as well as offline. Through empirical studies, Erstad argues, one can overcome traditional dichotomies and focus on young people's learning identities and practices in multiple settings.

John Furlong and Chris Davies focus on the home as an important context for the application of a holistic view of young people as well as a broader understanding of 'learning' than is often articulated in school and in public debates. They focus in particular on playful approaches to engagement with technology, and - in turn - learning 'new stuff', which is a distinctive feature of the practices that they studied.

Charles Crook challenges the notion of 'the digital native', which is an often contested term but one that is widely used to describe the generations born after the mid-90s, when the internet had become a common presence in private homes. Further, he challenges the equally frequent term 'Web 2.0'. He argues that the social and cognitive practices involved in the recreational use of Web 2.0 tools should not be understood as a set of common competencies, but must be understood in the light of the socio-cultural settings in which they take place. Moreover, Nick Selwyn emphasises the importance of taking young people's experiences into consideration in any analysis of young people, education and digital technologies. He also suggests a focus on the specific affordances of digital technologies in order to grasp the material enablements and constraints without falling into technological determinism.

Finally, Keri Facer suggests that new understandings of digital technologies and young people should provide the basis for new possibilities for change in the relationship between school, young people and the society that surrounds them. Digital technologies will have an increased impact on our lives in the centuries to come - and especially on our children's lives - and we therefore need to reflect upon how future generations can develop a careful, critical and ethical relationship to these technologies and to the society in which they exist. 
In 2016, Sonia Livingstone and Julian Sefton-Green published The Class: Living and Learning in the Digital Age. Over a period of more than a year, the two scholars followed a Year 9 class ${ }^{1}$ in a London suburb, spending time with the 13-14 year old children in school and out of school, in after school and extra-curricular activities, and in their private homes. Through a sensitive, methodological approach, which focuses on the social networks of each of the participants, they draw a rich and nuanced picture of 'the texture' of their everyday lives that allows them to describe the role of digital media in context. The project can be said to take its point of departure in the discussions outlined in Davies, Coleman and Livingstone (2014), while expanding the analysis through the individual voices of teenagers. Instead of basing discussions of children, young people and media on assumptions and theoretical concerns, Livingstone and Sefton-Green ask how childhood has actually changed and, accordingly, what digital media actually means in relation to new forms of childhood. In addition, the notion of change is taken into consideration, as the authors wish to shed light on the fact that when discussing children's and adolescents' current life circumstances, we often refer to a very specific understanding of 'the good childhood' that prevailed in the 50s and 60s. Today's individualized, complex and mediatized society provides different conditions for young people growing up, and they perceive an increasing pressure to make individual choices and perform well at all stages of their lives.

Through their careful empirical analysis, Livingstone and Sefton-Green point to the fact that members of what is often percieved as a 'super-connected' generation (Chayko, 2016) actually put a lot of effort into trying to keep the different spheres of their lives (school, family, friends online and offline) apart. When kids 'hang out' in online spaces, they can escape the watchful gaze of their parents and an ever more evaluation-based school culture, just as online spaces provide them with an opportunity to actually spend time with their friends, with whom they are often prevented from spending face-to-face time due to practical circumstances. Overall, however, the young people in the study have good and stable relationships with their parents, siblings, and extended family. Media such as television are often used as a shared activity in the home. In trying to liberate themselves from their parents, as all 13-14 year olds tend to do, they prefer to use media tools and platforms with which their parents are not familiar. Facebook, for instance, was not seen as the place for sharing secrets or expressing one's inner self, since everybody - including parents and teachers - was there.

'The Class' is the most recent of a rich collection of publications and talks related to the research project. The homepage of The Connected Learning Research Network offers a wide range of online resources, including blog posts, videos, and podcasts. ${ }^{2}$ The project aims at establishing a dialogue with stakeholders and policy makers in the field as well as with the public, thereby establishing a nuanced point of view in the frequently tense public debates on the topic.

The Class is well worth reading. The solid and sensitive analysis of independent yet vulnerable youngsters is particularly valuable, and the many different nuances and aspects 
brought forth cannot all be covered in this review. In sum, the two publications provide important contextualisations of what it is like to be a teenager in the 21st Century, and they show how digital media both form and challenge the everyday lives of young people across various settings. They ask the fundamental question of what digital media mean, and they provide interesting theoretical and methodological frameworks to come up with at least part of the answer, while giving voice to those for whom it matters the most.

\section{Notes}

1 Equivalent of a Danish grade 7

2 Which can be found here: http://clrn.dmlhub.net/projects/the-class\#updates

\section{References:}

Chayko, Mary (2016): Superconnected. The internet, digital media, \& techno-social life. London: Sage

Tække, Jesper \& Michael Paulsen (2016a): Undervisningsfallesskaber og laringsnetvark i den digitale tidsalder. Copenhagen: Forlaget Unge Pædagoger.

Tække, Jesper \& Michael Paulsen (2016b): Bildung in the Digital Medium Environment. Paper to The Third ISA Forum "The Futures We Want: Global Sociology and the Struggles for a Better World.Vienna, Austria, 10-14 July 2016.

Stine Liv Johansen

PhD, Associate Professor

Department of Communication and Culture

Aarhus University, Denmark

stineliv@cc.au.dk 